\title{
New Strategy to Reduce Water Consumption and Waste Generation During the Mechanical Milking Process in a Small Cattle Sector
}

\author{
Josemar Gonçalves Oliveira Filho ${ }^{1}$, Wagner Rodrigues Nascimento ${ }^{2}$, Simonny Monthiel Araújo Vasconcelo ${ }^{3}$, \\ Marcelo Gomes Judice ${ }^{2} \&$ Mariana Buranelo Egea ${ }^{3}$ \\ ${ }^{1}$ São Paulo State University (UNESP), School of Pharmaceutical Sciences, Araraquara, São Paulo, Brazil \\ ${ }^{2}$ Rio Verde University (UNIRV), Rio Verde, Goias, Brazil \\ ${ }^{3}$ Goiano Federal Institute of Education, Science, and Technology, Campus Rio Verde, Brazil \\ Correspondence: Josemar Gonçalves Oliveira Filho, Rodovia Araraquara-Jaú, km 1 - CP 174 - Machados, SP, \\ 14800-901, Brazil. E-mail: josemar.gooliver@gmail.com
}

Received: January 3, $2021 \quad$ Accepted: February 24, $2021 \quad$ Online Published: March 3, 2021
doi:10.5539/jms.v11n1p102

\begin{abstract}
Dairy cattle farming is an activity of great economic importance in Brazil; however, this activity presents high water consumption and volume of waste generated. The objective in the present work was to measure water consumption and waste generation during mechanical milking, in order to promote rational initiatives for the process. The farm property showed the consumption of $64.76 \%$ of the whole used water per day and generation of $35.24 \%$ of waste-water in the milking process. After orientation, the average coefficient of water consumption in the cattle sector decreased to 3.2 liters with a daily production of approximately 550 liters of milk and an average water consumption of 1,764.83 liters per day. The implementation of equipment and adoption of mitigation measures was associated with a significant reduction in water waste.
\end{abstract}

Keywords: dairy cattle, environmental management, water use

\section{Introduction}

Water is important for the emergence and support of life on the planet. Although the amount of water remains in constant dynamic circulation, it is vulnerable to changes in climatic conditions. In addition, local and global impacts and changes over the course of a hydrological year are factors that also change the distribution of water over time and space (Westall \& Brack, 2018).

Rationalizing the use of water is one of the main alternatives of a water resources management program, and it is essential to determine the quantity and quality level of water necessary for each use. The measures to reduce water consumption include the modification of procedures and exchange of equipment that consumes a large amount of water and that are already installed on the production line, as well as the search for new technologies and production procedures (Cambrainha \& Fontana, 2018).

Worldwide, Brazil is the second largest producer of beef and the sixth largest producer of milk and also has the largest commercial herd, with about 200 million animals involved in all this production (USDA, 2014). Milk is one of the most important agricultural products in the country, with an annual production of approximately 32 billion liters, representing about 5.0\% of world production (SEBRAE, 2014).

Livestock farming, especially in the case of intensive animal production systems, is potentially impacting the environment, as it generates a large amount of waste in the soil (Teston, 2010). The maintenance of equipment and utensils as well as the daily cleaning of the milking parlor are essential requirements for the hygienic production of milk. At the end of the milking process, it is recommended to remove feces and other residues such as the remains of feed and milk, among other residues that are carried out in a wet manner using water (Carvalho \& Ribeiro, 2002).

Milk production is responsible for generating a large volume of wastewater with a high polluting potential. When water management is performed inappropriately and in the absence of prior treatment before disposal, nutrients accumulate in the soil that can lead to eutrophication of water courses. The return of water from cleaning facilities to the environment is a problem that requires alternatives to reduce the environmental impacts 
that are generated in milk production (Decezaro, 2013). Willers et al. (2014) analyzed indirect water consumption in the milking process on a small farm in the state of Bahia (Brazil) and identified a high environmental impact associated with indirect water consumption throughout milk production (from milking to when the milk is sent to the dairy industry). The water consumption coefficient in the milking sector averaged $3.4 \mathrm{~L} / \mathrm{L}$ for milk produced ( $541 \mathrm{~L}$ of water consumed for $160 \mathrm{~L}$ of daily milk produced). The authors reported that the professionals who work in the milking and cleaning activities have little or no instructions on the proper use of water. In another study, Shine et al. (2018) analyzed the direct water consumption in 58 Irish dairy farms during 2014 and 2016, and observed a water consumption of $13.42 \mathrm{~L}$ water/L milk.

In view of the current scenario of intense population growth, concomitant with the great demand for water for public and industrial supply, it is necessary to promote rational and sustainable initiatives for the management of water resources, paying attention to preventive measures to rationalize and properly dispose of wastewater from traditional activities, such as dairy cattle. Thus, the present study aimed to measure water consumption and waste generation in mechanical milking on a rural property (Itarumã, Goias, Brazil), in order to promote rational initiatives to reduce water consumption and waste generation.

\section{Method}

The research was carried out in the dairy cattle sector on a rural property, located in the municipality of Itarumã

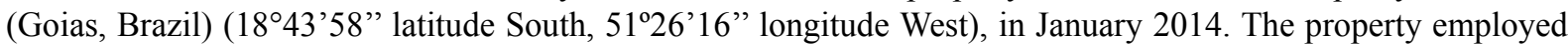
three employees in the milking sector and had a dairy herd content of 55 lactating Girolando animals, which were subjected to two daily milkings.

Water storage in the sector was carried out in a 200-liter drum (Figure 2), which was used to dilute the animals' feed ( 5 liters) and to clean the milking parlor. In the milking time, the animals were transferred from the sector ( $18 \mathrm{~m}$ long x $12 \mathrm{~m}$ wide, $216 \mathrm{~m}^{2}$ area) to the milking parlor ( $15 \mathrm{~m}$ long by $8 \mathrm{~m}$ wide, $120 \mathrm{~m}^{2}$ area).

The first stage of the present work was the description of the environments, procedures performed, and indication of the points where there was consumption and waste of water. The second stage of the present work was the determination of the volume of water consumed and wasted in the environment for observation over 15 days, totaling 30 milking processes. For this, the cubing method was used (Giordano, 2004). Briefly, the time it took the water to fill the 40-liter container was timed and using these data the flow (volume/time) was calculated. The water consumption was characterized by opening and using the connection of water in milking parlor (milking process on) and the waste generation was characterized by opening and unused the connection of water in milking parlor (milking process off).

The third stage was guidance on water consumption and waste generation. An orientation meeting lasted an hour and all employees (including the owner of the property) were present for a proposal to implement mitigating measures, reduce consumption, or wastewater. Mitigation measures included: using a Mac Loren revolver at the end of the water connection; changing the wet cleaning of the milking parlor (removal of animal feces) for dry cleaning with the use of shovels; using exclusive water washing for scraping the bays of the animals in the milking parlor; and cleaning when there is a significant accumulation of residue. Also, basic information about the correct use of water and its importance as a natural resource were taught for the whole team.

To assess the effectiveness of using the recommendations, the same determination was made for the second stage after 15 days, totaling 30 milking process ( 2 per days).

For the statistical analysis of the data, the t-test using statistical software SPSS 20.0 was performed to compare the means before and after the intervention.

\section{Results}

\subsection{Description of the Environment and Activities Evaluated}

In the evaluated environment, water was used to: 1) clean the dirty animal when it entering the milking parlor; 2) wash the udder to remove dirt before milking with the liners; 3 ) clean feces if the animal defecated while milking occured.

Before the milking process, the test for the detection of clinical mastitis was performed, aiming to detect clinical mamitis in the first milk samples. Figure 1 shows the internal view of the milking parlor with drum in the foreground. Throughout the milking procedure, an unused stream of water remained open.

After milking, the equipment, milking parlor, the gallons that stored the milk, the equipment, utensils that were used during the process, and the milk and feces on the floor were cleaned with water and liquid detergent. These activities were carried out by any of the sector's employees using continuous water flow. 


\subsection{Assessment of Water Consumption and Waste on the Property Before and After Recommendations}

Water consumption in the sector was achieved by using calculated flow of $0.1428 \mathrm{~L} / \mathrm{s}$ (40 liters $/ 280$ seconds). After training and the improvement of activities by employees, the flow rate of this water was $0.1176 \mathrm{~L} / \mathrm{s}(40$ liters $/ 340$ seconds), that is, there was a reduction of $18 \%$ in the use of water.

Table 1 shows the daily variations in water consumption and waste generation in the second stage of this work. The variation in water consumption and waste generation in milk production were the result of numerous factors, such as the number of milked animals, the techniques, and equipment used in the production stages, among others.

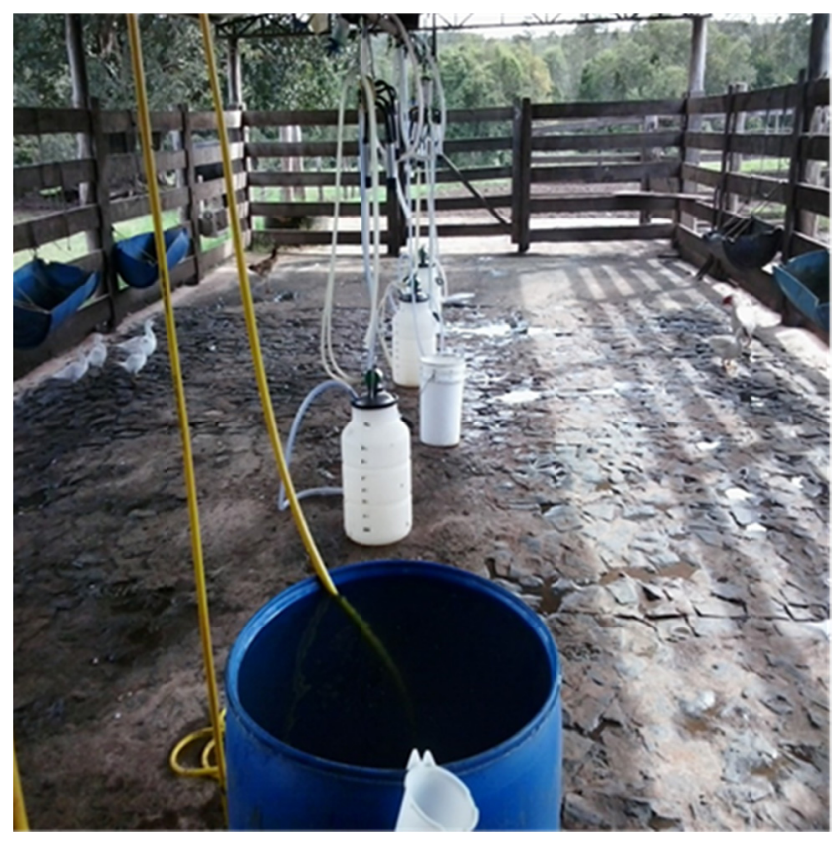

Figure 1. Internal view of the milking parlor on a rural property (Itarumã, Goias, Brazil)

Table 1. Total volume and consumption of water, as well as waste generation before and after recommendations during milking process of the milking sector on the days evaluated (values in liters).

\begin{tabular}{|c|c|c|c|c|}
\hline \multirow[t]{2}{*}{ Days } & \multicolumn{2}{|l|}{ Before } & \multirow[t]{2}{*}{ Waste } & \multirow[t]{2}{*}{ After Total volume } \\
\hline & Total volume & Consumption & & \\
\hline 1 & 3265.78 & 2191.48 & 1074.30 & 1617.45 \\
\hline 2 & 3274.35 & 2174.76 & 1099.59 & 1666.16 \\
\hline 3 & 3282.93 & 2217.77 & 1065.16 & 1666.39 \\
\hline 4 & 3284.64 & 2159.90 & 1124.74 & 1701.58 \\
\hline 5 & 3310.07 & 2193.20 & 1116.87 & 1638.16 \\
\hline 6 & 3282.93 & 2123.33 & 1159.60 & 1743.92 \\
\hline 7 & 3308.78 & 2125.62 & 1183.16 & 1701.69 \\
\hline 8 & 3317.35 & 2159.61 & 1157.74 & 1750.98 \\
\hline 9 & 3300.49 & 2100.18 & 1200.31 & 1743.93 \\
\hline 10 & 3360.36 & 2134.19 & 1226.17 & 1814.29 \\
\hline 11 & 3377.21 & 2142.75 & 1234.46 & 1877.70 \\
\hline 12 & 3421.07 & 2178.19 & 1242.88 & 1884.76 \\
\hline 13 & 3463.07 & 2177.33 & 1285.74 & 1870.76 \\
\hline 14 & 3445.78 & 2168.47 & 1277.31 & 1880.99 \\
\hline 15 & 3480.36 & 2245.62 & 1234.74 & 1913.69 \\
\hline Average & 3345.01 & 2166.16 & 1178.85 & 1764.83 \\
\hline
\end{tabular}

The variation in daily water consumption is mainly explained by the change in the number of animals submitted to the milking process. On the first day of evaluation, 50 animals were milked while at the last day of evaluation 
were 58 animals subjected to the milking process. In addition, the way animals are handled also directly influences water consumption and waste generation. Stressed animals urinate and defecate more than those not stressed and more water is spent to clean the milking parlor (Boissy et al., 2005).

Water consumption was $64.76 \%$ (2,166.16 liters) while total water generation was $35.24 \%$ (1,178.85 liters), which probably occurred due to the continuous unused water flow. The cleaning of floors, equipment, and the milking parlor were the activities that consumed the largest volume of water, since this practice was performed with continuous water flow without any control method to prevent water waste.

The average coefficient of water consumption in the studied sector decreased to 3.2 liters per liter of milk with a daily production of approximately 550 liters of milk, and an average water consumption of 1,764.83 liters daily. The dairy industry located in the Zona da Mata (Minas Gerais, Brazil) with a capacity of 4,000 liters/day, presented an average water consumption coefficient of 3.2 liters per liter of processed milk (Saraiva et al., 2009). In another dairy industry with a processing capacity of between 10,000 and 20,000 liters of milk per day, the average water consumption ratio was 3.0-4.5 liters per liter of milk (Machado et al., 2002)

Figure 2 shows the total volume of water consumed before and after the third stage of the present work. There was a significant reduction $(p=0.000)$ in the total volume of water $(43.26 \%)$ after the changes suggested and made in the use of water during the milking process. This reduction in total water waste can be explained by the use of a Mac Loren revolver at the end of the hose, preventing the continuous unused water flow.

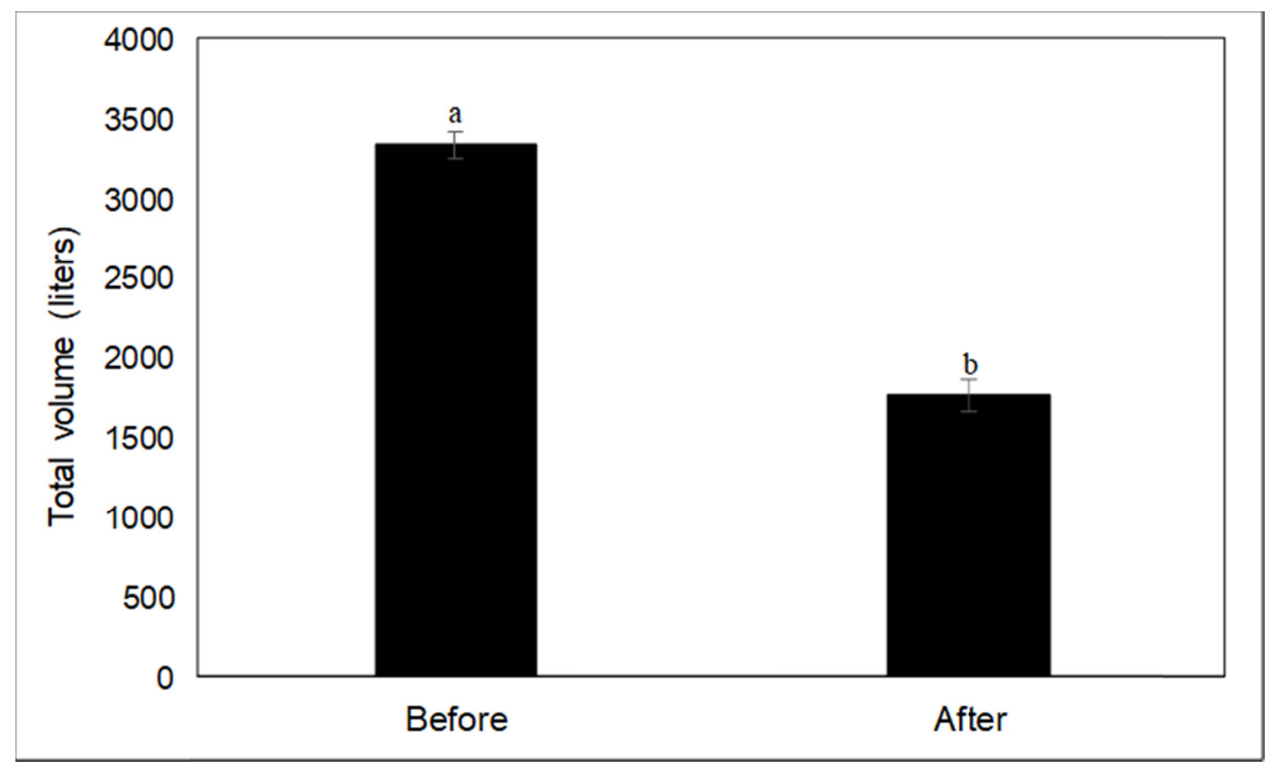

Figure 2. Total volume of water consumption before and after the third stage of the present work

After employees accepted the guidelines and changed the work procedures inside the milking parlor, water consumption also decreased. They combined physical removal by scraping feces, rations, and other residues, with washing with water. Training of employees and alteration of cleaning methods by more efficient methods are examples of practices that promote the prevention of water waste during milking and that in this work proved to be efficient. The replacement of automatic valves in hoses is a strategy for mitigating water flow and reducing costs as previously discussed in the literature (Saraiva et al., 2009). Employees can also choose to decrease the flow and increase the pressure of the hoses, so that it does not compromise the efficiency of the cleaning process (Embrapa, 2001).

The average coefficient of water consumption in the cattle sector studied was 4.3 liters per day production of approximately 500 liters of milk and an average water consumption of 2,166.16 liters per day, resulting in 4 liters of water per 1 liter of milk produced.

Due to the peculiarities of each productive sector, there is a discrepancy between the coefficients of water consumption in agribusiness (Brião \& Tavares, 2007). It should be noted that the discussion on the use of water in milking processes is small compared to the concern with the use of water by dairy products, which are processing industries for milked milk. 
Water is used for various purposes in dairy production such as washing floors, walls, equipment, and utensils containing impurities (Saraiva, 2008). The dairy industry demands large volumes of water for the production and cleaning process, resulting in significant flows of liquid effluents (ranging from 1 to $7 \mathrm{~m}^{3}$ effluent $/ \mathrm{m}^{3}$ processed milk) containing nutrients, infectious agents, and persistent organic substances. Machado et al. (2006) emphasize the importance of implementing and optimizing wastewater treatment systems in conjunction with the identification of critical points that generate liquid waste in the production process.

According to Paiva et al. (2009), it is possible to promote a $75 \%$ reduction in water consumption when washing equipment on dairy cattle properties by replacing hoses with buckets. The lack of training and awareness of employees regarding good environmental practices is a factor justifies the deficiencies in the production lines that result in wasted water and the lack of standardization of cleaning methods (Castro, 2007).

Although the recommended measures have been effective, it is necessary to continue using the proposed recommendations of this program, so that the quantity and quality of water on the property can be preserved.

\section{Acknowledgments}

This research was funded by IF Goiano (23218.000305.2021-12).

\section{References}

Boissy, A., Fisher, A. D., Bouix, J., Hinch, G. N., \& Le Neindre, P. (2005). Genetics of fear in ruminant livestock. Livestock Production Science, 93(1), 23-32. https://doi.org/10.1016/j.livprodsci.2004.11.003

Brião, V. B., \& Tavares, C. R. (2007). Effluent generation by the dairy industry: Preventive attitudes and opportunities. Brazilian Journal of Chemical Engineering, 24(4), 487-497. https://doi.org/10.1590/S0104-66322007000400003

Cambrainha, G. M., \& Fontana, M. E. (2018). A multi-criteria decision making approach to balance water supply-demand strategies in water supply systems. Production, 28. https://doi.org/10.1590/0103-6513.20170062

Carvalho, A., \& Ribeiro, A. C. (2002). Ordenha mecânica: implantação e operação. Viçosa - MG. CPT.

Castro, V. C. (2007). Diagnóstico do consumo de água e geração de efluentes e de resíduos sólidos em um laticínio de pequeno porte. Doctoral dissertation, Dissertação (Mestrado em Ciências e Tecnologia de Alimentos)-Universidade Federal de Viçosa, Viçosa.

Decezaro, S. T. (2013). Tratamento de águas residuárias de bovinocultura de leite no Brasil - Situação atual e possibilidades. Universidade Federal de Santa Maria.

EMBRAPA - Embrapa Gado de Leite. (2001). Tratamento e manejo de dejetos bovinos. Retrieved September 16, 2019, from http://www.cnpgl.embrapa.br/nova/informacoes/pastprod/textos/52Instrucao.pdf

Giordano, G. (2006). Tratamento e controle de efluentes industriais. Rio de Janeiro-RJ, 2004.

Heller, L., \& Pádua, V. L. (2006). Abastecimento de Água para Consumo Humano. Belo Horizonte: Editora da UFMG.

Machado, E. L., Kist, L. T., Kich, R. O. M., \& Schneider, L. (2006). Gestão tecnológica ambiental de uma indústria de laticínios: ênfase em efluentes. In Congreso Interamericano de ingeniería sanitária y ambiental. Ponta del Este.

Machado, R. M. G., Freire, V. H., Silva, P. C., Figueredo, D. V., \& Ferreira, P. E. (2002). Controle ambiental em pequenas e médias indústrias de laticínios. Belo Horizonte - MG: Projeto Minas Ambiente.

Mierzwa, J. C. (2002). O uso racional e o reúso como ferramentas para o gerenciamento de águas e efluentes na indústria estudo de caso da Kodak Brasileira. Doctoral dissertation, Universidade de São Paulo.

Paiva, R. B., Milani, I. C. B., Nebel, A. L. C., Tavares, V. E. Q., Suzuki, L. E. A. S., \& Collares, G. L. (2009). Implantação de técnicas de produção mais limpa em uma propriedade de gado leiteiro. In XVIII Congresso de Iniciação Científica, XI Encontro de Pós-Graduação e I Mostra Científica, Universidade Federal de Pelotas.

Saraiva, C. B. (2008). Potencial poluidor de um laticínio de pequeno porte: um estudo de caso. Doctoral dissertation, Dissertação de mestrado. Programa de Pós-graduação em Ciência e Tecnologia de Alimentos, Universidade Federal de Viçosa, Viçosa.

Saraiva, C. B., Mendonça, R. C. S., Santos, A. L., \& Pereira, D. A. (2009). Consumo de água e geração de efluentes em uma indústria de laticinios. Revista do Instituto de Laticínios Cândido Tostes, Juiz de Fora, 64, 
(367/368).

SEBRAE - Boletim Setorial do Agronegócio No 03. (n.d.). Bovinocultura leiteira. Retrieved May 7, 2017, from http://189.39.124.147:8030/downloads/Boletim-Bovinocultura.pdf

Shine, P., Murphy, M. D., Upton, J., \& Scully, T. (2018). Machine-learning algorithms for predicting on-farm direct water and electricity consumption on pasture based dairy farms. Computers and Electronics in Agriculture, 150, 74-87. https://doi.org/10.1016/j.compag.2018.03.023

Teston, D. C. (2010). A produção de energia a partir de esterco bovino como solução ambiental para impactos gerados por sistemas intensivos de produção animal. Monografia para conclusão de Curso de Especialização em Gestão Ambiental e Negócios do Setor Energético do Instituto de Eletrotécnica e Energia da Universidade de São Paulo (pp. 1-45). São Paulo.

UNITED STATES DEPARTMENT OF AGRICULTURE-USDA. (2014). Dairy: Word markets and trade. Washington, July 2014. Retrieved August 10, 2014, from http://apps.fas.usda.gov/psdonline/psdHome.aspx

Westall, F., \& Brack, A. (2018). The importance of water for life. Space Science Reviews, 214(2), 50. https://doi.org/10.1007/s11214-018-0476-7

Willers, C. D., Ferraz, S. P., Carvalho, L. S., \& Rodrigues, L. B. (2014). Determination of indirect water consumption and suggestions for cleaner production initiatives for the milk-producing sector in a Brazilian middle-sized dairy farming. Journal of Cleaner Production, 72, 146-152. https://doi.org/10.1016/j.jclepro.2014.02.055

\section{Copyrights}

Copyright for this article is retained by the author, with first publication rights granted to the journal.

This is an open-access article distributed under the terms and conditions of the Creative Commons Attribution license (http://creativecommons.org/licenses/by/4.0/). 